\title{
SOME REMARKS ON THE IDEOLOGICAL CORE AND POLITICAL PILLARS OF THE SO-CALLED ISLAMIC STATE
}

\begin{abstract}
The article focuses on the ideological pillars of the ISIS or the so-called Islamic State and aims to explain the ideological core of the ISIS by examining the roots and pillars of this extreme terrorist Jihadists, Wahhabist and Salafist organization. The article seeks and explores the roots in Jihadism, radical form of Salafism and partially radical Arab nationalism, but it also looks partially at the "legacy" of Saddam Hussein's regime (1979-2003) in Iraq (many former high ranked officers of Saddam's military, BAATH party and also several intelligence officers were actively involved in ISIS) and the Arab post-colonial and post-cold war world.
\end{abstract}

Keywords: ISIS, Salafi Jihadism, Wahhabism, Arab nationalism, terrorism.

\section{INTRODUCTION}

\subsection{The aim of article}

The review article ${ }^{3}$ focuses specifically on the ideological core (Fadel, 2019; Bunzel, 2015; Todenhöfer, 2016) of ISIS $^{4}$ and aims to explain it by showing that the ideological

\footnotetext{
${ }^{1}$ Vladimir Sazonov, PhD, Estonian Military Academy, Estonian Academy of Security Sciences and Centre for Oriental Studies at University of Tartu, Lossi 3, 51003, Tartu, Estonia (corresponding author); e-mail: sazonov@ut.ee. ORCID: 0000-0001-9738-1329.

2 Illimar Ploom, PhD, Estonian Military Academy, Tartu, Riia 12, 51013; e-mail: illimar. ploom@gmail.com. ORCID: 0000-0003-2950-7553.

3 The authors of this study partially rely on date used in earlier articles (Sazonov, Sazonov, 2019 and Mölder, Sazonov, 2019).

${ }^{4}$ ISIS (Islamic State of Iraq and Syria) or Daesh (its Arabic-language acronym) is a radical and an extremist Salafist and Jihadist movement whose founder is considered to be Jordanian Abu Musad al-Zarqawi (1966-2006). It is known that al-Zarqawi founded the movement in 2006, a few years after the 2003 invasion of Iraq by Western coalition forces. Initially the movement was called the Islamic State of Iraq (October 2006 - April 2013), and later renamed as the Islamic State of Iraq and Sham (April 2013 - June 2014), and the Islamic State (June 2014 - present) (Bunzel, 2015). Bunzel (2015) has highlighted that „founded by al-Qaeda in Iraq, the Islamic State emerged at a time when Iraq's Sunni insurgency was fast losing momentum. It is significant that al-Qaeda was involved in founding the movement, while it was later joined by several large and small Islamist groups, such as Islamic Jihad". The first leader of the Islamic State of Iraq was Abu Omar al-Baghdadi, who was assassinated in 2010. The last known leader of ISIS was Abu Bakr
} 
core of ISIS or so-called Islamic State is rooted not merely in extreme Islamist views, such as radical Salafism and Jihadism (Kepel, 2006) or specifically Salafi Jihadism ${ }^{5}$ and Wahhabism, but ISIS have also borrowed from certain elements of Arab nationalism, which is legacy of the post-colonial Arab world. What is more, ISIS have managed to skilfully design effective online information campaigns for influencing different audiences in many regions. Finally, it must be borne in mind that there are also certain political facets in Islamic fundamentalism that cannot be overlooked. Those political facets, in turn, come with the inter-cultural historical dimension, whereby the changes within a specific religion should be seen in the context of wider cultural and socio-political changes and pressures.

The authors do not aim to conduct an 'anatomic' dissection of the ideological foundation of ISIS, instead the aim of this article to give a brief overview of certain central ideological elements and political pillars of ISIS.

\subsection{Data sample and methodology}

To that end, the authors analysed primary sources [e.g. the ISIS propaganda (Milton, 2018)] film "Flames of War" (ISIS Releases Propaganda Video: Flames of War, 2014) that relies uses religious narratives and symbols as well as current literature on radical Jihadism and ISIS's ideological base. Qualitative content analysis was applied in this study to analyse the collected data by using a hidden pilot sample on the basis of which primary coding was performed (Kracauer, 1953; Kuckartz, 2014). A substantive analysis of a large number of articles was conducted after the pilot study during which the content of specific texts as well as the words, sentences in the articles and also in video materials was analyzed.

\subsection{Regional and global situation for creation of ISIS: an overview}

In today's Middle East, dangerous extremist forces are becoming increasingly visible, especially after the Arab spring (Danahar, 2014) and with the escalating politics of chaos in the region (Roy, 2008) and more powerful - especially Islamist (Martin, Barzegar, 2010) religious fanatics and terrorists, (Hübsch, 2001) such as the more radical branches of Salafism. (Mölder, Sazonov, 2019; Mölder, 2019; Mölder, 2021) Several of these religious extremist groups (Rubin, 2009) are very active in the Middle East and even in the West. This is especially true in Syria, a country enmeshed in a bloody civil war (Peterson, 2016) for the past eight years (since March 2011) and where in 2014, radical Islamists succeeded in establishing a terrorist quasi-state called "the Caliphate" or the Islamic State of Iraq and Syria (ISIS) (Bunzel, 2015; Mölder, 2021) on the territories nominally belonging to Syria and Iraq. As Fraser et al. have stated:

At the beginning of 2013, an emergent Sunni group, known as the Islamic State of Iraq, began a series of attacks in the country, while in April, the formation of

al-Baghdadi, killed in 2019. Current leader of ISIS is Abu Ibrahim al-Hashimi al-Qurashi (since 31 October 2019). For more on ISIS, see Burke, 2015.

5 Salafi jihadism is a religious-political ideology, which is based on ideas of "physical" jihadism and the Salafi ideological base and pillars. The term "Salafist jihadist" was used by G. Kepel in 2002 with the aim of describing the hybrid nature of radical Islamist ideology that originated with international Islamist fighters and jihadists during the Soviet-Afghanistan war as the jihad waged against Soviet invasion (Livesey, 2005).

6 The Caliphate was declared by the leaders of ISIS in June 2014 and the title of Caliph was given to their leader Abu Bakr al-Baghdadi (1971-2019), originally named Ibrahim Awad Ibrahim al-Badri. 
the Islamic State of Iraq and Levant (ISIL), drawing on support in both Iraq and Syria, was announced. Calling itself the Islamic State, in June the organisation declared the Caliphate (Fraser, Mango, McNamara, 2017).

As Marc Lynch (2016) remarked, "the failure of the Arab uprisings and the emergence of the Islamic State has revitalized a critique of Islamist movements which had fallen into disrepute".

By the end of 2020, ISIS had lost these previously controlled territories in Iraq and Syria. Nevertheless, although ISIS can be currently deemed mostly defeated from a military point of view, its ideological ideas, key leaders, and thousands of fighters sustain the threat of potential re-establishment of the Islamic State in the Middle East. Thus, ISIS as such has yet to truly be defeated (Ianes, 2019).

In addition, radical - and often politically motivated - religious groups have become more and more visibly influential, especially by using information warfare (Zgryziewicz, Grzyb, Fahmy, Shaheen, 2015). R. Zgryziewicz has highlighted the following with regard to ISIS's information war tactics:

Visuals, words, and actions have been effectively used for shaping the information environment. Daesh has adopted the strategy of creating its own version of the symbols that internationally recognised countries use, i.e. the flag, anthem, emblems, and organizational structure. These are intrinsic to Daesh's communication strategy. The group advertises its good management practices, declarations of support from other organisations recognised within its community of support, as well as their operational successes. By highlighting its achievements and emphasizing its future plans, Daesh strives to inspire hope, excitement, and confidence in those people who are inclined to believe in them. To counter these 'legitimising narratives' it is important to observe how the group communicates, both internally and externally (Zgryziewicz, 2016).

In the past decades, religiously motivated fundamentalist (New, 2002) political movements and extremist terrorist organizations (e.g. ISIS, Al-Qaeda etc.) have become extremely influential in the Middle East. They have even been able to change both the regional and global security environment, making it more unstable, dangerous and explosive. To that end, they often use religion and religious narratives, phenomena and ideas, as tools for influencing their target audiences and, of course, as an instrument for achieving their political and ideological aims (Mölder, Sazonov, 2019).

The global context adds here its layers of meaning. In the following analysis the fundamentalist nature of Islam will be mostly separated from the external context. Nevertheless, it must be acknowledged that Islamic radicalism has certain obvious although not easily ascertainable links with the Western-Muslim politics. As much as peculiarly the form is concerned, the fundamentalist features can partly be attributed to the long-standing exposure of Muslim cultures to the globally and regionally dominating Western culture and economic as well as political ideologies. While there can be detected an impact emanating from this problematic relationship of the West and Islam which has shaped the radicalist form of the latter, this relationship has also significantly influenced the assumptions, conditions of existence and the possibility of success of the West in its policies in the Middle 
East. To attend first the wider issues of this problematic Western-Muslim politics, they are perhaps best visible by way of looking at the aftermath of the Arab Spring. Indeed, keeping in mind Western expectations about democratisation of the region (even if in slow pace), its outcomes have been controversial. On the one hand, it saw the fall of autocratic leaders (e.g. in Tunisia, Egypt and Libya), but the ensuing chaos often paved the way not merely for a return to traditional roots but also, for the rise of Islamists (even if moderate, like the Muslim Brotherhood) (Rózsa et al., 2012). Thus, from the perspective of the West, the outcomes of the Arab Spring have been varied. Only the Tunisian example supports the argument of democracy being clearly on the winning side ${ }^{7}$, whereas some countries have witnessed the return of autocratic regimes (e.g. Egypt, where the army has once again assumed control), (Abdelsalam, 2015) while many others (e.g. Libya, Yemen, Syria) have devolved into civil war (Mushtaq, Afzal, 2017).

Such developments carry an implicitly discouraging message for the West. The modern Western approach entails two different aspects of legitimisation that both seem to be working against its success in the Middle East. First of all, in order to legitimise its activities in the Middle East, the West needs to justify these actions at home. With some notable exceptions, (Cohen-Almagor, 2018) most of the Western measures have been geared towards supporting democratisation, from the direct export of democracy, to conditional aid, or to the general advocacy for human rights. Thus far, this has been the only argument for legitimating these policies in the West in order to secure public support as well as financial backing from the parliaments. However, as the above mentioned events have demonstrated, this particular goal may be both positively and negatively detrimental to Western aspirations in the Middle East: positively detrimental in the sense that the impulse to seek popular legitimacy in the region may lead to unexpected consequences as locals may opt for returning to (however distorted version of) their traditional values, and negatively detrimental, as democracy is perceived by the locals as part and parcel of the Western way of life imposed on the region.

The imposition of Western values and way of life constitutes the second problematic aspect of legitimising the West's actions in the Middle East and has to do with the relatively long dominance of the Western civilisation over the Islamic World (i.e. the colonial past, effects of globalised capitalism, the legacies of the Cold War etc.). The consequences of these historical and a myriad of internal developments paved the way for the ruling regimes and sometimes, in turn, for the counter-movements that emerged as a result (e.g. in postrevolutionary Iran, Iraq, Afghanistan etc.). In this context, it is not surprising that the West has also gradually grown tired of sustaining its active efforts in the Middle East, especially considering that its interventions have not managed to bring peace to the region. In some cases, the outcomes may even seem antithetical and counterproductive.

In this context, one could also perceive the uneasiness that relates to the role of the West in the rise of ISIS. Indeed, by way of simplification, it could be argued that ISIS's emergence is itself partly a consequence of Western interventions in the Middle East and beyond. Furthermore, it is possible to draw a link between the 2003 Western intervention in Iraq, the consequent dismantling of Saddam Hussein's army and the rise of ISIS. While

\footnotetext{
${ }^{7}$ In Tunisia, liberals and the moderate Islamic party cooperated in an emerging multi-party system (For more, see Natil, 2016).
} 
this does not mean that the West should assume responsibility for ISIS's actions, an indirect relationship can hardly be denied ${ }^{8}$.

Despite high hopes, the toppling of Saddam Hussein's regime did not bring about peace. On the contrary - Iraq descended into civil war (incl. against the U.S. and its allies) that lasted for eight years. When the U.S. forces finally left Iraq in 2011, the situation in the country deteriorated, becoming even more unstable, eventually falling prey to another civil war. It was in this context that radical Islamists were successful in establishing a terrorist quasi-state - in the form of 'the Caliphate' under the name Islamic State of Iraq and Syria (ISIS) - in the territories seized from Syria and Iraq in 2014 (Bunzel, 2015). It must be borne in mind that in the Middle Eastern cultural space, religion is still very closely intertwined with politics, just as it was in ancient times (Mölder, Sazonov, 2016).

This enmeshment is prevalent to such an extent that they are often impossible to separate from one another. What is more, these theological systems can even be used by religious extremists to justify their crimes and violent (Selengut, 2003) methods (e.g. warfare, terrorism, deportations, intolerance towards other religious or ethnic groups), which they often utilise to achieve their political objectives (Mölder, Sazonov, 2019; Mölder, Sazonov 2021).

This begs the question: what is the underlying foundation of ISIS's programme in the radical religious-ideological context? In broad terms, it is the same as that of all Islamists the Quran and the Sharia law are all-encompassing, conveying a holistic framework to make sense of the world (Mölder, Sazonov, 2016). However, it must be borne in mind that ISIS is also a Jihadist and fundamentalist radical Salafi ${ }^{9}$ movement that idealises the early medieval Muslim world of Prophet Muhammad, and strives to return to the early days of Islamism as their official credo. Essentially, ISIS's ideology comprises several universal and skilfully compiled narratives. Some of them are borrowed from the early Islamic traditions, others from modern extremism, radical Salafism (Qutbism), Wahhabism, as well as Arab nationalism, while also drawing on successful practices of Western PR campaigns. (Sazonov, 2014b).

Cole Bunzel, an American expert on Wahhabism, has analysed the ideology of ISIS by dividing its history into several clearly distinguishable periods or stages. According to Bunzel (Bunzel, 2015), the first stage was the genesis of the idea of ISIS "in what is called the Zarqawi prelude (2002-2006), the period of jihadism's initial rise in Iraq under the leadership of Abu Musab al-Zarqawi (1966-2006)". The second stage of ISIS's ideological development was the period of the Islamic State of Iraq (2006-2013), which Bunzel (2015) describes as "a largely failed attempt at state formation coinciding with jihadism's decline in the country". The next or third stage was the Islamic State of Iraq and Sham (2013-2014), "which saw the much-delayed success of the Islamic State idea in the group's expansion to Syria. The fourth is that of the Islamic State as the outright Caliphate (2014 - present)" (Bunzel, 2015).

What are ISIS's aims? ISIS wants to restore the Arab society to the early days of Islam, and as such, its main objective is to return to the roots of Islam, consequently rejecting all reforms and all innovation that have occurred within Islam and in Muslim religious customs and understandings. According to ISIS's views and understanding, all changes are bound

\footnotetext{
${ }^{8}$ See e.g. (Jones et al., 2017). Even this, otherwise critical account, admits that 'ISIL did grow out of chaos that sprung from the US invasion of Iraq' (Hundal, 2015; Milne, 2015).

${ }^{9}$ Not all Salafists can be considered radical and violent.
} 
to corrupt the original and pure nature of the Islam of Muhammad's era. Thus, their goal is to promote the Wahhabist ideological approach that aims to restore the Caliphate of the $7^{\text {th }}$ century. ISIS's leaders believe that this new Caliphate should be governed in accordance with Salafist doctrine and Sharia law ${ }^{10}$. Of course this official vision needs to be corrected to reality, since no actual return is really feasible, and even the idea of choosing the purest form of Islam is itself primarily a political decision.

\section{SALAFISM AND WAHHABISM AS THE MAIN IDEOLOGICAL PILLARS OF ISIS}

What are Salafism and Wahhabism? The ultraconservative Sunni Muslims are known as Salafi and they idealize the person of the Prophet Muhammad and the first caliphs who lived in the $7^{\text {th }}$ century. The official goal of the Salafi is to return to the roots and origins of Islam - to a society, to the concepts and values of the early $7^{\text {th }}$ century. The term "Salafism" is defined as "a school of thought which surfaced in the second half of the 19th century as a reaction to the spread of European ideas, seeking to expose the roots of modernity within Muslim civilization" (Mölder, Sazonov, 2019).

For ultraconservative Sunni Muslims, Prophet Muhammad's life and that of the first Caliphs, including all their words and deeds, constitute the fundamental basis for interpreting Islamic law and religious dogma. The ideologists of Salafi movements emphasize their desire to turn back the wheels of history, striving to establish a direct link with the life of Mohammad and his period. In this context, one of the most prevalent Salafi terms is al-Wahhābiyya, originated by Islamic preacher and a well-known scholar Muhammad ibn Abd al-Wahhab who was pressured by his opponents to denounce his teachings as mere personal opinion (Mölder, Sazonov 2019). The scholar al-Wahhab and his followers called themselves al-Muwahhidūn, meaning "those who profess the unity of God" (Pink, 2010). In the $20^{\text {th }}$ century this term has been appropriated by the followers of the Salafi, for example Sulaymān bin Saḥmān (Mölder, Sazonov, 2021).

ISIS has tried to build its ideological foundation on Salafism and Wahhabism, specifically a radical branch called Qutbism or Jihadist Salafism. However, Salafism itself, as a movement and ideology, does not automatically refer to radical Islamism or terrorist ideology. Owing to that, it should also be noted that as an ideology, Salafism does not constitute one uniform, extremist authority as has been depicted in the media after the 2001 terrorist attacks in New York and other terrorist acts in Madrid, Paris, Berlin and London etc. (Mölder, Sazonov, 2019).

Although there exist more ways to classify the object, this article distinguishes between three distinct branches within the Salafi movement. First, there is the non-violent and peaceful Purist branch of Salafism, seeking to promote mainly religious goals, ideas and Islamic education. The second branch of Salafi movements is known as Madkhalist Salafism, which is close to the Purists, mainly comprising the followers of Saudi Arabian Islamic scholar Rabee al-Madkhali ${ }^{11}$. The Madkhalist Salafi support secular state-building

${ }^{10}$ The ideology of the Islamic State of Iraq and the Levant. Wikipedia.

${ }^{11}$ Born in 1931 in Saudi Arabia, Rabee' Ibn Haadee 'Umayr al-Madkhalee is the head of the Sunnah Studies Department at the Islamic University of Madinah in Medina, Saudi Arabia. He is a famous Salafist scholar, and is considered to be the leader and founder of the Madkhali-Salafi movement. 
in the Arab world, claiming that secular leaders have been granted a divine right to rule their countries (Mölder, Sazonov, 2021).

The third Salafi branch is the most populous branch of the Salafi movement, usually referred to as mainstream Salafism or political Salafism. It condemns violence, but contrary to the Purist and Madkhalist branches, they are quite actively engaged in the political processes in their home countries and societies (Mölder, Sazonov 2021).

Fourthly, the most infamous, but less popular branch of Salafism is Jihadism, a radical branch that is used by organizations such as ISIS and other Islamist terrorist organizations. This radical Salafi Jihadism has gathered strength, especially since the mid-1990s, using terrorism, sabotage, information war, cyber-attacks, violence, various means of hybrid warfare as their main instruments against secular regimes and governments, and also against non-Muslims, but also against Shia Muslims, whom they consider apostates (Mölder, Sazonov 2019, but against several Sunni Muslims too which do not support or follow the ideology of ISIS.

\subsection{ISIS and QUTBISM}

As mentioned above, Salafism has many different branches and movements, including some more or less moderate or radical movements, with different degrees of politicisation, etc. One of its radical branches is called Qutbism, and it has served as a major influence on the ideological foundations of the al-Qaeda organization, as well as ISIS and others.

Qutbism was named after its founder Sayyid Qutb (1906-1966), (Kepel, 2002, 30-32) one of the leaders of the Muslim Brotherhood in Egypt in the 1950-60s. As highlighted by Kepel "Qutb's early inspiration had come from the Brothers - but at the end of his life, he was able to draw conclusions from their failures as well as their successes, and to confront the new situation created by the disappearance of colonialism and the rise of an independent state that was hostile to Islamist ideals" (Kepel, 2002).

According to Qutb, Islam is a comprehensive system of morality, law, and management, all governed by the principles of Sharia law. Qutb's main contribution to Islam is his 30volume edition of commentaries to the Quran called "In the Shade of the Qur'ān". Originally known as a secular and progressive scholar, Qutb turned to fundamentalist Islamism in the course of his studies in the United States during the late 1940s. Interestingly, although Qutb welcomed the "Free Officers" movement led by Gamal Abdel Nasser and their coup to overthrow the ruling Egyptian king Farouk in 1952, he soon fell into deep conflict with the new rulers, ultimately spending ten years (1954-1964) in prison where he wrote his famous political manifesto of Islamism "Milestones" (Ma'alim fi-l-Tariq). Two years later, in 1966, Qutb was executed by hanging (Mölder, Sazonov 2019, 22).

Sayyid Qutb's younger brother Muhammad (1919-2014) was also a follower of Islamism and its ideological patterns, eventually moving to Saudi Arabia. He taught Islamic studies and his students included future radical terrorist al-Qaeda leaders such as Osama bin Laden and Ayman az-Zawahiri. It is worth mentioning that Muhammad Qutb's magnum opus "Islam: The Misunderstood Religion" (Shubuhāt Hawla al-Islam) is considered one of the foundational writings of the fundamentalist and radical path of Islamism that promotes Islamic moral superiority over the Western world as well as its ideas and values (Mölder, Sazonov 2021, 22).

Thus, in essence, ISIS draws heavily from the Qutbist branch of Salafism, using and promoting the ideas and views of such Islamist scholars and spokesmen as Sayyid Qutb, Abul A'la Maududi, Hassan al-Banna, etc. As described above, Qutbism is an extreme 
Islamist ideology "that advocates violent jihad to establish governance according to sharia (Islamic law). It is believed to be the foundational ideology of today's most dangerous violent Islamist groups, including al-Qaeda and ISIS"12.

\title{
3. ISIS AND JIHADISM
}

One of the pillars of ISIS is Jihadism and for that reason we should begin by defining the term jihad (Kepel, 2002; Peterson, 2005), one of the many central and strong narratives that correspond to the mind-set of certain Muslims, especially those who are radicalised. According to Middle Eastern understandings, the term jihad (now mostly used to denote terrorism, radical Islamists or suicide attacks) is more or less equivalent to the Western concept of ius ad bellum, defining the circumstances of a just war. The famous Islamic scholar Ibn Khaldun (1322-1402) has discussed the terms of 'just' and 'unjust' wars in his major work Muqaddimah ("Introduction") (Bahrani, 2008; Mölder, Sazonov, 2016).

Asma Afsaruddin, Professor of Arabic and Islamic studies, defines Jihad in the following manner:

\begin{abstract}
Jihad, (Arabic: "struggle" or "effort") also spelled jehad, in Islam, a meritorious struggle or effort. The exact meaning of the term jihad depends on context; it has often been erroneously translated in the West as 'holy war'. Jihad, particularly in the religious and ethical realm, primarily refers to the human struggle to promote what is right and to prevent what is wrong. In the Qur'an jihad is a term with multiple meanings. During the Meccan period (c. 610-622 CE), when the Prophet Muhammad received revelations of the Qur'ān at Mecca, the emphasis was on the internal dimension of jihad, termed sabr, which refers to the practice of "patient forbearance" by Muslims in the face of life's vicissitudes and toward those who wish them harm. The Qur'ān also speaks of carrying out jihad by means of the Qur'ān against the pagan Meccans during the Meccan period (25:52), implying a verbal and discursive struggle against those who reject the message of Islam. In the Medinan period (622-632), during which Muhammad received Qur'ānic revelations at Medina, a new dimension of jihad emerged: fighting in self-defense against the aggression of the Meccan persecutors, termed qitāl. In the later literature - comprising Hadith, the record of the sayings and actions of the Prophet; mystical commentaries on the Qur'ān; and more general mystical and edifying writings - these two main dimensions of jihad, sabr and qitāl, were renamed jihād al-nafs (the internal, spiritual struggle against the lower self) and jihād al-sayf (the physical combat with the sword), respectively. They were also respectively called al-jihād al-akbar (the greater jihad) and aljihād al-asghar (the lesser jihad) (Afsaruddin, sine anno).
\end{abstract}

The martyrs of Allah is one of the main ideas of jihad. This is well illustrated by following passage: "By He in whose hand my self is! I would like to fight in the way of Allah and be killed, then he brought to life again so I could be killed, and then be brought to life again so I could be killed" (Peters, 2005, 21).

${ }^{12}$ Qutbism. Counter Extremist Project, https://www.counterextremism.com/threat/qutbism; West Point: Combating Terrorism Center, Parameters: The U.S. Army War College Quarterly, p. 86. 
Thus, Jihad (Rashid, 2002) is a broad term and does not always denote violent deeds and holy war against non-Muslims. Secondly, embedded deep in the ideological foundation of ISIS is radical Salafi Jihadist ideology, itself, in turn, based on

the violent exploitation of Salafist tenets and the strict interpretation of Islamic law, which is manifest in Sharia. The ideologues of the Islamic State seek to govern every aspect of their follower's life and base their actions on dogmas of the Quran and Hadiths that are shaped according to their understanding (Mölder, Sazonov, 2016).

It has been argued that Salafi Jihadists have taken the most extreme passages from the Quran (Holy Qu'ran 1993) and the Hadiths (Бертон, 2006) to justify violent and radical actions, in essence, abusing Islam. (Williams, 2015) The jihadists call on their supporters to start a religious war and in this they rely on modern ideologists but also on the Quran. For example, the Quran (9:29-30) says:

The Jews say, "Ezra is the son of Allah"; and the Christians say, "The Messiah is the son of Allah." That is their statement from their mouths; they imitate the saying of those who disbelieved [before them]. May Allah destroy them; how are they deluded? (Holy Qur'an 1993; Salama, 2018).

\subsection{SALAFI JIHADISM}

Salafi jihadism is a religious-political ideology which is based on the beliefs and ideas of jihadism and the ideological core of the Salafi movement. The term 'Salafist jihadist' was introduced by Gilles Kepel in 2002 with the aim of describing hybrid Islamist radical ideology which was developed in the 1980s by international Islamist fighters during the Soviet-Afghan War as jihad against the Soviet invasion (Livesey, 2005).

The ideology of the Islamic State propagated by ISIS, is based on Salafi jihadism, who consider jihad as its essential element. To illustrate their understanding of Jihad, the authors offer the following excerpt from a speech by one of the leaders of the Islamic State of Iraq, Abu Omar al-Baghdadi:

We believe that jihad in God's path is an individual obligation, from the fall of al-Andalus until the liberation of [all] Muslim lands, and [that it is an individual obligation] in the presence of a pious person or an impious person. And [we believe that] the greatest of sins after disbelief in God is barring from jihad in God's path at the time when it is an individual obligation. Ibn Hazm said: "No sin after disbelief in God is greater than the sin of forbidding jihad against the unbelievers and commanding the surrender of the Muslim's women to them on account of the sinfulness of a Muslim man whom others do not call to account for his sinfulness (Bunzel, 2015).

\section{FUNDAMENTALISM AS A POLITICAL PHENOMENON}

As indicated in the chapter on Salafism and Wahhabism, the Salafi ideology can be seen as a $19^{\text {th }}$ century response to European influence on Islam. This idea deserves a more in-depth analysis as it provides an extra layer of backdrop for understanding the radical fundamentalist movements within Islam. 
First of all, it would be expedient to outline in more detail the direct and indirect influence of European and Western culture on the emergence and development of Islamic fundamentalism and radicalism. The main pressures can be most explicitly seen in the form of European colonisation as the history of Western colonisation has hardly left any Muslim nation untouched (McDonnell, 2010). For consequences of the post-colonial choices in Sudan which may have side-lined moderate Islamic schools (see Massoud, 2018). While it is difficult to define Islamic fundamentalism as a straightforward response to the felt impacts of European pressure, this line of argument cannot be entirely cast aside either (Emerson, Hartman, 2006).

Indeed, this article approaches Islamic radicalism partly as a response of a traditional culture in danger of losing its roots and, in order to revitalize them, turning to its sources with the aim of establishing a strict set of rules. This strictness is meant to provide a feeling of security and thus, radicalisation can be seen as a way of overcoming the inner insecurity of a community or people. As such, fundamentalism could hardly be seen as a purely religious phenomenon. In essence, and in existential terms, it is much more political, seeking to condition individual thought and behaviour into following the 'right path' as prescribed by religious doctrine. Although nowadays, fundamentalism is primarily associated with Islam, it originally acquired its name from Christian fundamentalists in America where certain groups of immigrants felt endangered by the changing interpretation of the Bible ${ }^{13}$, with particularly strong opposition emerging against the German hermeneutical school of Bible interpretation. However, it is possible to pinpoint even earlier examples of Christian fundamentalism, such as early modern Calvinist regimes in Switzerland (e.g. in Geneva, Basel and Zürich) (Mansbach, 2006).

In this context, the changes brought on by modernity could be said to have prompted a fundamentalist response which focused on the rules of the right way of life. While ostensibly focusing on Christian theology, its actual effect was the establishment a radical theocratic regime that issued strict prescriptions on everything from food and clothing to schooling. In short, by interpreting the Bible as a straightforward prescription of righteous living, these regimes can be deemed fundamentalist and, in $20^{\text {th }}$ century parlance, totalitarian.

Several fundamental differences notwithstanding, a similar basic pattern can also be observed with Islamic fundamentalism. A perceived, either real or imaginary, threat to a traditional way of life prompts a radical fundamentalist response that digs deep into the spiritual scriptures of a people, yet exemplifies a political rather than religious move to save the traditional way of life. When speaking about Islamic radicalism, we should always keep that political aspect in mind, and although it cannot be expected to explain everything, it brings the otherwise self-restricted phenomenon out of isolation and opens it up for a more practical interpretation.

\section{RELIGIOUS NARRATIVES USED AS PROPGANDA TOOLS}

To begin with, it is necessary to clarify a couple of things to truly understand the ideological foundations of Islamic religious fanaticism, and the concept of jihad (Bukay, 2007; Mölder, Sazonov, 2016) in the beginning of the $21^{\text {st }}$ century and how it is used by

${ }^{13}$ For insights into how Darwin's ideas of evolution were perceived by the $19^{\text {th }}$ century American Protestant fundamentalists (see Trollinger, Trollinger, 2017). 
ISIS from an ideological point of view. First of all, we should ask what constitutes the ideological basis of ISIS. The most important cornerstone of Islamist movements is, naturally, the Quran. In 1938, renowned Islamist theologian Hassan al-Banna (1906-1949) (Kepel, 2002), founder of the movement Muslim Brotherhood (Aboul-Eneim, 2013; Kepel, 2002), declared: "Allah is our ideal. Prophet is our leader. Qur'ān is our law" (Hirsi Ali, 2011; Mölder, Sazonov, 2016).

ISIS has utilised religious ideas and narratives for propaganda purposes. For example, in their propaganda video "Flames of War" (ISIS Releases Propaganda Video: Flames of War, 2014), where Jihadists speak about the Caliphate, disbelievers or non-believers (kafir), Tawhid (Arabic, 'unification or oneness of Allah'), and jihad.

Essentially, all Islamic fundamentalists (Davidson, 1998) follow the same dogma. In 2014, the leaders of ISIS declared the Caliphate, headed by a Caliph, following the example of the medieval Islamist state established in the $7^{\text {th }}$ century. The name - the Caliphate - was later appropriated by the Ottoman Empire, where the Sultans, rulers of that empire, also took the title of Caliphs. Today, this concept has been used once more, this time by ISIS. The Caliphate certainly seems to be a brand that is remarkably popular, while also being quite simple and easy to understand, and most importantly, readily available to use in propaganda videos (see e.g., ISIS Releases Propaganda Video: Flames of War, 2014) etc., not requiring a special public relations campaign. That seems to be the main reason why it has been appropriated by ISIS, very successful in conducting information warfare, as an influential propaganda weapon (Al-Tamimi, 2017).

Thus, ISIS has actively used the historical narrative of the Arab Caliphate, which historically existed from 632 to1258, as its foundational as well as aspirational pillar. According to Holger Mölder $(2019 ; 2021)$ "it claimed to have authority over the whole Muslim world, and through its affiliated organizations, as well as territories in the Middle East and North Africa controlled by the Islamic State".

Many of ISIS's ideological leaders and spokesmen claim that their main goal is the establishment of a pure and undistorted Islam of Muhammad's era and the original Caliphs (Salafi views). However, this seems to be simply a useful tool for influencing people and attracting potential supporters to their ranks. Daesh propaganda, before and after its collapse. Countering violent extremism (2019).

ISIS has also used various controversial religious sayings, ideas and narratives from the Quran, often containing violent messages (ISIS Releases Propaganda Video: Flames of War, 2014). H. Hassan (2015) has pointed out that "ISIS depends heavily on what Muslim clerics consider isolated incidents described in sacred texts that it believes should not be followed as rules". The authors agree with Hassan (2015) who has correctly remarked that "because ISIS bases its teachings on religious texts that mainstream Muslim clerics do not want to deal with head on, new recruits leave the camp feeling that they have stumbled on the true message of Islam".

For example, Abu Omar al-Baghdadi ${ }^{14}$, one of the original leaders of the Islamic State of Iraq, similarly to other leaders of this organization, often quoted the Quran (Holy Qur'an, 1993) in his speeches (Bunzel, 2015), for example:

\footnotetext{
${ }^{14}$ Abu Omar al-Baghdadi (1959-2010), born Hamid Dawud Muhammad Khalil al-Zawi, was the leader of the militant group Mujahideen Shura Council, who fought against the U.S. forces in the Iraq War. From 2006 to 2010 he served as the 1st emir of the Islamic State of Iraq.
} 
Whoso judges not according to what God has revealed - they are the unbelievers (Quran 5:44).

The Satans inspire their friends to dispute with you; if you obey them, you are idolaters (Quran 6:121).

In addition, the authors further offer a selection of passages from the Quran (Holy Qur'an, 1993) which radical Islamists (e.g. ISIS, etc.) may use for their ideological and propaganda purposes, for justifying their actions and criminality (e.g. raping girls etc.) (Khanna, 2015; Esman, 2015; ISIS Propaganda Video: Flames of War, 2014)

Quran (2:191) - "Slay them wherever you find them and drive them out of the places whence they drove you out, for persecution is worse than slaughter".

Quran (3:56) - "As to those who reject faith, I will punish them with terrible agony in this world and in the Hereafter, nor will they have anyone to help".

Quran (2:19) - "Kill them wherever you find them. Drive them out of the places from which they drove you".

Quran (8:12) - "I will cast terror into the hearts of those who disbelieve. Therefore strike off their heads and strike off every fingertip of them".

Quran (3:151) - "Soon shall we cast terror into the hearts of the Unbelievers, for that they joined companions with Allah, for which He had sent no authority."

Quran (48:29) - "Muhammad is the messenger of Allah. And those with him are hard (ruthless) against the disbelievers and merciful among themselves".

These types of violent and extreme passages are often picked by ISIS from the Quran to justify their violent and radical actions. (ISIS Releases Propaganda Video: Flames of War, 2014).

This is supported by Afsaruddin's argumentation, claiming that

Islamist extremists have used the rubric of jihad to justify violent attacks against Muslims whom they accuse of apostasy. In contrast to such extremists, a number of modern and contemporary Muslim thinkers insist on a holistic reading of the Qur'ān, assigning great importance to the Qur'ān's restriction of military activity to self-defense in response to external aggression (Afsaruddin, sine anno).

The jihadists, on the other hand, call on their supporters to wage a religious war, referring to both modern ideologists but also to the Quran:

Fight those who do not believe in Allah or in the Last Day and who do not consider unlawful what Allah and His Messenger have made unlawful and who do not adopt the religion of truth from those who were given the Scripture - [fight] until they give the jizyah willingly while they are humbled (Qur'ān, 9:29-30) (Holy Qur'an 1993).

We know that Abu Bakr al-Baghdadi (McCants, 2015), the Caliph of the Islamic State of Iraq and the Levant (ISIL) from 2013 to 2019, studied theology and Islamic studies, and therefore knew very well how to effectively use such religious narratives for these purposes. 
What is more, as his official title, he took the name - Abu Bakr - of the very first Caliph of the Arab Caliphate, Abu Bakr Abdullah ibn Uthman (632-634), the first legitimate successor of Prophet Muhammad and also Muhammad's father-in-law. Abu Bakr alBaghdadi purported himself as the leader of all Muslims and the vicar of Allah on Earth. Furthermore, as the Caliph, Abu Bakr al-Baghdadi also took the name Ibrahim, a common name among Muslims; however, it bears noting that Ibrahim is also the Arabic name of God's messenger, the prophet Abraham. ISIS and its leaders claimed that their chosen leader, Caliph Ibrahim, was the founder of the new Caliphate or the man leading the restoration of the Caliphate as it was in $7^{\text {th }}$ century, at the time of Muhammad and the first Caliph Abu Bakr. Furthermore, they maintained that only Abu Bakr al-Baghdadi is the legitimate successor of Prophet Muhammad and holds the true vision for the development and future of the Caliphate (Stern, Berger, 2016).

R. Zgryziewicz, an expert on ISIS's information warfare, has pointed out:

In his first speech, the self-claimed Caliph, Abu Bakr al-Baghdadi, announced his plans to build a Muslim state and his expectations for re-establishing the Caliphate. The organization came up with a unique value proposition - the unification of the Muslim world in a newly declared state to experience the sacred benefits of as a part of the Ummah. By articulating these future benefits, Daesh was able to capture the attention and interest of specific target audiences. By June 2014, already 12,000 foreign fighters from 81 countries had joined in the fighting in Syria's civil war (Zgryziewicz 2016).

The idea of establishing a pan-Arabic Caliphate is not new, dating back to the first Caliphs who ruled in the $7^{\text {th }}$ century. The territory of the ISIS Caliphate or the Islamic State of Iraq and the Levant (ISIL), whose establishment was declared by their newly chosen leader Abu Bakr al-Baghdadi, was located in eastern parts of Syria and in western Iraq. Subsequently, ISIS strove to expand the territory of its Caliphate by trying to conquer the rest of Syria and Iraq, with a long-term plan to take control over Lebanon, Israel and Palestinian territory as well as invading Egypt and eventually expanding the Caliphate across the whole of North Africa and the Middle East, the Caucasus, with even the Balkans and Spain ultimately foreseen to come under Islamic rule (ISIS: Portrait of a Jihadi Terrorist Organization 2014). This idea, propagated by ISIS, of a 'Caliphate' to unify all Muslims, was of course a utopia, but it was successfully used as a narrative of an 'ideal state of god on Earth' mainly for propaganda purposes.

For propaganda purposes, ISIS also uses the name of God (Allah) ${ }^{15}$, which carries strong religious connotations. Their aim is to show that Allah supports jihadists and that they are his loyal warriors. For the same reason, it was decided that the flag of ISIS would be black, carrying the following text in the Arabic language: La 'ilaha 'illa-llah - "There is no God but God" (Prusher, 2014). This flag also includes a shahada (Islamic statement of faith), which corresponds to all Muslims of the world to Umma. In addition, it has also been pointed out that

around the edges is the white circle in the middle of the ISIS flag with three words inside it: "God Messenger Mohammed." It's an interesting choice of word order

${ }^{15}$ For an example of how ISIS has used Allah's name in their propaganda, see ISIS Releases Propaganda Video: Flames of War 2014. 
given that the second part of the shahada is "and Mohammed is God's messenger" (Prusher, 2014).

The black colour of the flag and adding the word 'Allah' to this flag, "merges two powerful narrative themes" (Zgryziewicz 2016, 99). Interestingly, Prophet Muhammed's war banner was also black and thus, the flag of ISIS "refers to the origin of Islam and points to the future for believers by also representing the day of the final battle in Dabiq and resurrection" (Zgryziewicz 2016, 99).

In addition, ISIS has also used Islamic eschatology, the idea of the Day of Judgment, very forcefully, even by naming one of their online propaganda magazines "Dabiq". According to Islamic eschatology, Dabiq ${ }^{16}$ is the settlement where 'the Final Battle' between believers and non-believers is to take place. And when the rule of Caliphate has been established globally, peace will come to all people in the world. As Zgryziewicz has correctly stated "The 'Dabiq prophecy' is end-of-days story that pits the forces of Islam against the Christian West". In Islamic eschatology, as found in the Hadith, the area of Dabiq is mentioned as the place of some of the events of the Muslim Malahim (equivalent to the Christian idea of an apocalypse). Abu Hurayrah, a companion of Prophet Muhammad and one of the most prolific narrators of Hadith, reported that Muhammad once said:

The Last Hour would not come until the Romans land at al-A'maq or in Dabiq. An army consisting of the best of the people of the earth at that time will come from Medina [to defeat them] (Zgryziewicz 2016).

It should be noted that ISIS's online magazine "Dabiq" promoted Jihadism, religious and political violence and genocide by using the name of God (Alhayat Media Center 2015; Alhayat Media Center 2015; Inside the ISIS propaganda machine, 2019). In addition, referring to the Day of Judgment was also an important and crucial element of ISIS's communication strategy (Zgryziewicz, 2016).

\section{ELEMENTS OF ARAB NATIONALISM AND XENOPHOBIA}

The emergence of ISIS was also influenced by Saddam Hussein's foreign policy (Sazonov, 2014b) of militant plans and military ventures that had negative consequences for Iraq, with the Iran - Iraq war of the 1980s as just one example..$^{17}$ The Iran - Iraq (1980-1988) war lasted for eight years and devastated the whole region, being one of the bloodiest episodes in the long opposition and conflict between the Arabs and Persians that dates back to as early as the $7^{\text {th }}$ century Arab conquests in the Middle East (Sazonov, 2012).

This lengthy and bloody war brought the relatively economically stable and quite wealthy state to its knees. Its adversary, Iran, several times larger and economically stronger, ultimately managed to weaken and demoralise the Iraqi army. The Arab nationalism that was at the time strongly promoted by Saddam Hussein and his followers (some of them later joining ISIS), who promoted xenophobia against the Kurds (specifically targeted by Saddam Hussein's genocidal policies), Jews, Persians, and religious groups

\footnotetext{
${ }^{16}$ Dabiq is a town in northern Syria, about 40 kilometres (25 mi) northeast of Aleppo and around 10 $\mathrm{km}(6.2 \mathrm{mi})$ south of Syria's border with Turkey. See more Patrikarakos, 2016.

${ }^{17}$ For more on the Iran-Iraq war cf. (Fawcett, 2005; Karsh, 2010).
} 
such as Yazidis, Christians and the Shia, was taken by ISIS as one of its foundational ideological tenets (Sazonov 2014a; Spencer, 2007; Stern, Berger, 2016).

Similarly to ISIS, Saddam's policies were largely founded on xenophobia and included the spreading of fear and threatening with deportation and terror, actively used against the citizens of Iraq. These kinds of nationalistic roots are clearly visible also in the case of ISIS. The hatred targeting Kurds or Yazidis, widespread among ISIS fighters, reflects partly the Arab nationalist views of Saddam Hussein and his xenophobic policy towards the Kurds, Yazidis etc. (Cheterian, 2019).

However, it must be borne in mind that the 'nationalism' of ISIS is not the same as was prevalent during Saddam Hussein's reign, mainly because this strand of Arab nationalism is heavily influenced by Salafism and other Islamist ideas. What is more, ISIS fighters come from all over the world and as a result, this organisation is also very international.

In 2007, the German newspaper "Frankfurter Allgemeine Zeitung" published an article about the legendary Middle Eastern rulers Saladin and Nebuchadnezzar II ${ }^{18}$ (ruled 605-562 BC) as role models, noting that Saddam's year of birth (1937) coincided with the estimated $800^{\text {th }}$ anniversary of the birth of Saladin (ruled 1174-1193, born 1137 in Tikrit), the first sultan of Egypt and Syria, one of the most famous medieval rulers of the Arab world (Cf. Hermann, 2007; Sazonov, 2014b). When Saddam Hussein learned this, he undoubtedly used it to his advantage. It was also important for Saddam that he and Saladin both originated from Tikrit and, just like Saladin, Saddam wanted to unite the Arabs under his rule and to ultimately become as powerful and revered as Saladin once was. Saddam Hussein was also interested in ancient Mesopotamian kings - for example, brutal Neo-Assyrian king Sennacherib (Frahm, 1997) (ruled 704-681 BC), and Nebuchadnezzar II the most famous ruler of the Neo-Babylonian Empire, who deported Jews from Jerusalem in $587 \mathrm{BC}$ - whose life experiences held plenty of lessons about regimes and establishing empires, and by using this historical knowledge, Saddam hoped to legitimize his power with their help. (Sazonov, 2014b) In a political biography of Saddam Hussein, author R. J. Updike highlights the following issues regarding Saddam's imperialistic views and his antiSemitism:

The rulers of Mesopotamia were especially attractive for Saddam not only because of their remarkable position in the region but also because of their military advances in Palestine. Sennacherib ... the successor of Sargon II, invaded Palestine and, although he did not manage to conquer Jerusalem, he defeated some important cities in Judea and received a large impost from the king of Judah, Hezekiah. Where Sennacherib did not succeed, Nebuchadnezzar was a success: in $587 \mathrm{BC}$, after the uprising of the Jews in Palestine, he destroyed the kingdom of Judah and Jerusalem, including the Temple of Judah, and sent thousands of Jews to Babylon. Saddam often talked of this historic event and admitted that he would very much like to follow the example of the great Babylonian king (Apdayk, 1999) $)^{19}$.

Similarly to Saddam, the leaders of ISIS strive to unite all Arabs under their rule, using the concept of the Caliphate, as well as Arab nationalist narratives and the nationalist

18 On Nebuchadnezzar II see (da Riva, 2008; da Riva, 2013; Sazonov, 2014a).
19 See also (Spencer 2007; Sazonov, 2014b). 
sentiments of local people. It is reported that Saddam Hussein hated Jews and Iranians and he disliked the Kurds. In his youth, Saddam Hussein was strongly influenced by his uncle Khairallah Talfah, an extreme Arab nationalist and an official of the Iraqi Ba'ath Party, who took him into politics and later became Saddam's father-in-law (Sazonov, 2014a) In addition, Saddam and the Ba'ath party were also heavily influenced by the ideas of PanArabism and the Arab nationalism of Gamal Abdel Nasser, long-time President of Egypt (1954-1970) (Jillani,1991). Writing about former officers of Saddam's regime, Isabel Coles and Ned Parker have reported the following:

Saddam-era officers have been a powerful factor in the rise of Islamic State, in particular in the Sunni militant group's victories in Iraq last year. Islamic State then out-muscled the Sunni-dominated Ba'ath Party and absorbed thousands of its followers. The new recruits joined Saddam-era officers who already held key posts in Islamic State. The Ba' athists have strengthened the group's spy networks and battlefield tactics and are instrumental in the survival of its self-proclaimed Caliphate, according to interviews with dozens of people, including Ba'ath leaders, former intelligence and military officers (Cole, Parker, 2015).

According to some sources, at least over 100 former members of Saddam's military and intelligence officers are now actively involved in ISIS (Cole, Parker, 2015). What role have they played in ISIS? It has been reported that former officers of Saddam's regime helped to devise ISIS's military strategies, establishing its organization and discipline, while also integrating military operations with such terror tactics as suicide bombings, i.e. utilising the methods of hybrid warfare. It is also known that several of ISIS's leadership positions have been occupied by former members of the Ba'ath Party (Sly, 2015). In 2003, the last year of Saddam Hussein's reign, Iraq's security structures were already strongly influenced by Salafism, with many members of its intelligence services reported to have ties with radical Salafists (e.g. Samir Abd Muhammad al-Khlifawi aka Haji Bakr, previously a colonel in the Iraqi Intelligence Service, and later a senior leader of ISIL, heading its Military Council and leading its operations in Syria until being killed by Syrian rebels in January 2014) (Reuters, 2015). Before 2003, when the U.S. invaded Iraq, al-Khlifawi had been a colonel in the Iraqi Army, and had experience in working on weapons development and in the intelligence services of Saddam Hussein's Air Defence Corps at Habbaniya Air Base in Iraq. According to the same sources (i.e. Iraqi journalist Hisham al-Hashimi), Haji Bakr was "a nationalist, not an Islamist" (Reuters, 2015). Thus, one of the creators and leaders of ISIS was an Arab nationalist and a colonel in Saddam's army.

In conclusion, it can be surmised that ISIS has some connections with the Arab nationalist legacy of Saddam's regime and we know that many former high-ranking officers of Saddam's army, prominent members of Iraq's ruling Ba'ath Party, have later played significant and in some cases even key roles in ISIS. We also know that many of them were Arab nationalists, at least during the period of Saddam Hussein's reign. Did their views change? It could be argued that in ISIS, there seems to exist some kind of mixture, a hybrid ideology and a Ba'athist-Salafist nexus. Undoubtedly, the so-called Islamic State is effectively trying to introduce radical Salafist doctrine to mobilize its followers and also to recruit fighters from outside of Iraq and Levant. However, it is important to stress that ISIS does not rely only on the Salafi Jihadist doctrine, because ISIS is also at least partly controlled by former Ba'athist Iraqi officers that are mostly represented ideologically by 
Saddam era Arab nationalists who played a critical role in the establishment and leadership of ISIS (Natali, 2015).

\section{CONCLUSION}

ISIS's ideological core or foundational tenets are not based on purely religious narratives and motives. The Quran and Hadiths, Sharia law as well as radical and conservative Islamic views and understandings (e.g. radical Salafism, Wahhabism, and Salafi Jihadism) are not the only ideological pillars of ISIS; instead, their leaders, spokesmen and propagandists have selectively used violent and radical interpretations of sacred Islamic texts to justify their crimes, violence and genocide conducted against religious and ethnic minorities primarily in Syria and Iraq.

This is related to another essential core element of ISIS's ideology - Arab nationalism and xenophobia. However, although Arab nationalism is not strongly promoted by ISIS, it is still discernible in their approach via xenophobia and genocide of religious and ethnic groups. What is more, some prominent founders and leaders of ISIS, such as Haji Bakr, formerly served in the Iraq armed forces under Saddam Hussein, whose underlying ideology was primarily nationalist, not Islamist. Although we did not research the issue and roots of the elements of Arab nationalism in ISIS' ideology, it seems that this variation of Arab nationalism is partially a legacy of Saddam Hussein's regime whose despotic and brutal rule was extremely xenophobic towards many religious and ethnic groups in Iraq and beyond (e.g., Iranians, Yazidis, Kurds etc.). As reported, a large number of former members of the Iraqi Ba'ath Party and high-ranking army officers later joined ISIS, not to mention the fact that they participated in creating and in leading this terrorist organization. Therefore, it should not be a surprise that they incorporated, a least partially, their Arab nationalist and xenophobic views, ideas and understandings in the core ideology of ISIS.

Finally, the historical inter-cultural dimension bears emphasising as well. Islamic radicalism and fundamentalism cannot be properly understood without looking at these developments in the wider context of social, political and cultural pressures. In that regard, although it takes quite grotesque forms, Islamic radicalism also carries an element of political protection of their traditional way of life.

\section{REFERENCES}

Abdelsalam, E. (2015). The Arab Spring: Its Origins, Evolution and Consequences... four years on. "Intellectual Discourse", Vol. 23(1).

Aboul-Eneim, Y. (2013). Al Ikhwan al Muslimism: The Muslim brotherhood. "Military Review", Vol 3.

Afsaruddin, A. Jihad. (sine anno) [In:] Encyclopaedia Britannica [Access: 16.2.2021]. Access on the internet: https://www.britannica.com/topic/jihad

Al-Tamimi, A. (2017). The Myth of ISIS's Strategic Brilliance. "The Atlantic”, 20 July 2017 [Access: 22.2.2020]. Access on the internet: https://www.theatlantic.com/international/ archive/2017/07/isis-defeat-plan/534330/

Apdayk, R. Dzh. (1999). Saddam Khuseyn: politicheskaya biografiya. Rostov-na-Donu: Feniks.

Bahrani, Z. (2008). Rituals of War. The Body of Violence in Mesopotamia. New York: Zone Books.

Berton, D. (2006). Musul'manskoye predaniye: vvedeniye v khadisovedeniye. Moskva-Sankt-Peterburg: Dilya. 
Bunzel, C. (2015). From Paper State to Caliphate: The Ideology of the Islamic State. "The Brookings Project on U.S. Relations with the Islamic World. Analysis Paper No. 19, March 2015 [Access: 22.2.2020]. Access on the internet: https://www.brookings.edu/ wp-content/uploads/2016/06/The-ideology-of-the-Islamic-State.pdf

Burke, J. (2015). The New Threat from Islamic Militancy. The Bodley Head, London.

Cheterian. V. (2019). ISIS genocide against the Yazidis and mass violence in the Middle East. "British Journal of Middle Eastern Studies, Vol. 46.

Cohen-Almagor, R. (2018). US-Saudi Arabia Relations: Business as Usual? "Extraordinary and Plenipotentiary Diplomatist”, Vol. 6(10), October [Access: 22.2.2020]. Access on the internet: https://diplomatist.com/globalcenterstage/article20181029.html

Cole, I., Parker, N. (2015). How Saddam's men help Islamic State rule. "Reuters", 11 December 2015 [Access: 1.2.2020]. Access on the internet: https://www.reuters.com/investigates/ special-report/mideast-crisis-iraq-islamicstate/

da Riva, R. (2008). The Neo-Babylonian Royal Inscriptions. An Introduction. Guides to the Mesopotamian Textual Record. Vol. 4. Münster: Ugarit-Verlag.

da Riva, R. (2013). Nebuchadnezzar II's Prism (EK 7834): A New Edition. "Zeitschrift für Assyriologie”, Vol 103(2).

Daesh propaganda, before and after its collapse. Countering violent extremism (2019). NATO Strategic Communications Centre of Excellence, Riga [Access: 22.2.2020]. Access on the internet: https://stratcomcoe.org/download/file/fid/80922

Danahar, P. (2014). The Middle East. The World after the Arab Spring. London-New Delhi-New York-Sydney: Bloomsbury.

Davidson, L. (1998). Islamic Fundamentalism. Westport, Connecticut: Greenwood Press.

Emerson, M. O., Hartman, D. (2006). The Rise of Religious Fundamentalism. "Annual Review of Sociology". Vol. 32 (2006).

Esman, A. R. (2015). ISIS Rapes Women toward Allah. "The Investigation Project on Terrorists". 23 October 2015 [Access: 22.2.2020]. Access on the internet: https://www. investigativeproject.org/5013/isis-rapes-women-toward-allah

Fadel, M. (2019). Ideas, Ideology, and the Roots of the Islamic State. "Critical Review. A Journal of Politics and Society", Vol. 31(1).

Fawcett, L. (2005). International relations of the Middle East. Oxford-New York: Oxford University Press.

Frahm, E. (1997). Einleitung in Sanherib-Inschriften. Selbstverlag des Instituts für Orientalistik der Universität Wien. Horn: F. Berger \& Söhne G.m.b.H.

Fraser, T. G., Mango, A., McNamara, R. (2017). Making the Modern Middle East. London: Gingko.

Hassan, H. (2015). The secret world of Isis training camps - ruled by sacred texts and the sword. "The Guardian", 25 January 2015 [Access: 1.12.2020]. Access on the internet: https://www.theguardian.com/world/2015/jan/25/inside-isis-training-camps

Hermann, R. (2007). Saladin und Nebukadnezar als Vorbild. "Frankfurter Allgemeine Zeitung”, 2 January 2007 [Access: 7.10.2020]. Access on the internet: https://www.faz.net/aktuell/ politik/ausland/saddam-hussein-saladin-und-nebukadnezar-als-vorbild-1385362.html

Hirsi Ali, A. (2011). The Quran Is Our Law; Jihad Is Our Way. "The Wall Street Journal, Opinion", 11 February 2011 [Access: 27.10.2020]. Access on the internet: https://www.wsj.com/articles/SB10001424052748704132204576136590964621006 
Holy Qur'an (1993). Translated by M. H. Shakir. Qum, Islamic Republic of Iran: Ansariyan Publications P.O.B. 37185/187.

Hübsch, H. (2001). Fanatische Krieger im Namen Allahs: die Wurzeln des islamischen Terrors. Die Deutsche Bibliothek. München: Heinrich Hugendubel Verlag.

Hundal, S. (2015). ISIL's terrorism is not a reaction to Western foreign policy. "Quartz", November 18 [Access: 20.2.2021]. Access on the internet: https://qz.com/553733/isilsterrorism-is-not-a-reaction-to-western-foreign-policy/

Ianes, E. (2019). ISIS has been waiting for this very moment as Trump-fueled chaos in Syria helps it regroup. "Business Insider", 15 October 2019, [Access: 22.10.2020]. Access on the internet: https://www.businessinsider.com/isis-could-regroup-amid-trump-fueled-chaos-insyria-2019-10

Inside the ISIS propaganda machine (2019). "CBS News", 25 November 2019 [Access: 6.10.2020]. Access on the internet: https://www.youtube.com/watch?v=2rOVBTqN9XI

ISIS Releases Propaganda Video: Flames of War (2014). “The Rubin Report”, 17 September 2014 [Access: 6.10.2020]. Access on the internet: https://www.youtube.com/ watch?v=jAoH0Xr5a8c

Jillani, A. (1991). Inside the ISIS propaganda machine. Nasser, Saddam and Pan-Arabism."Pakistan Horizon” No. 2, Vol. 44.

Jones, S. G., Dobbins, J., Byman, D., Chivvis, C. S., Connable, B., Martini, J., Robinson, E., Chandler, N. (2017). Rolling Back the Islamic State. RAND report [Access: 20.2.2021]. Access on the internet: https://www.rand.org/pubs/research_reports/RR1912.html.

Karsh, E. (2010). Iraani-Iraagi sõda 1980-1988, Tallinn: Koolibri.

Kepel, G. (2002). Jihad. The Trail of Political Islam. The Belknap Press of Harvard University Press. Cambridge, Massachusetts.

Kepel, G. (2006). Jihad: The Trail of Political Islam. London: I. B. Tauris.

Khanna, T. (2015). Islamic State militant rapes 12-year-old girl, uses Quran to justify it. "Zeenews", 14 August 2015 [Access: 17.05.2020]. Access on the internet: https://zeenews.india.com/news/world/islamic-state-militant-rapes-12-year-old-girl-usesquran-to-justify-it1647059.html

Kracauer, S. (1953). The Challenge of Qualitative Content Analysis. "The Public Opinion Quarterly", Vol. 16, No. 4.

Kuckartz, U. (2014). Qualitative Text Analysis: A Guide to Methods. Practice \& Using Software. London: Sage Publications.

Livesey, B. (2005). The Salafist Movements. "Frontline” [Access: 11.05.2020]. Access on the internet: https://www.pbs.org/wgbh/pages/frontline/shows/front/special/sala.html

Lynch, M. (2016). The New Arab Wars. Uprisings and Anarchy in the Middle East, Public Affairs, New York.

Mansbach, R. (2006). Calvinism as a Precedent for Islamic Radicalism. "The Brown Journal of World Affairs”, Winter/Spring 2006, 12 (2).

Martin, R. C., Barzegar, A. (eds.) (2010). Islamism, Contested Perspectives on Political Islam. Stanford University Press. Stanford, California.

Massoud, M. F. (2018). How an Islamic State Rejected Islamic Law. "The American Journal of Comparative Law", Vol. 66, Issue 3, September 2018.

McCants, W. (2015). The Believer: How an Introvert with a Passion for Religion and Soccer Became Abu Bakr al-Baghdadi, the Leader of the Islamic State, Brookings Institution, 
September 1, 2015 [Access: 6.110.2020]. Access on the internet:http://csweb. brookings.edu/conten/research/essays/2015/thebeliever.html

McDonnell, T. M. (2010). The West's Colonization of Muslim Land and the Rise of Islamic Fundamentalism in The United States, International Law, and the Struggle Against Terrorism, [Access: 6.10.2020]. Access on the internet: http://digitalcommons.pace.edu/ lawfaculty/833/

Milne, S. (2015). Now the truth emerges: how the US fuelled the rise of Isis in Syria and Iraq. "The Guardian", June 3 [Access: 20.2.2021]. Access on the internet: https://www. theguardian. com/commentisfree/2015/jun/03/us-isis-syria-iraq.

Milton, D. (2018). Pulling Back the Curtain: An Inside Look at the Islamic State's Media Organization. West Point, NY: Combating Terrorism Center.

Mölder, H. (2019). The Islamic State, Clash of Civilizations and Their Impact on the Development of Contemporary International Relations. [In:] Sazonov, V., Mölder, H., Espak, P. (eds.). Cultural Crossroads in the Middle East: The Historical, Cultural and Political Legacy of Intercultural Dialogue and Conflict from the Ancient Near East to the Present Day. Tartu: University of Tartu Press.

Mölder, H. (2021). The Islamic State, Clash of Civilizations and Their Impact on the Development of Contemporary International Relations. [In:] Sazonov, V., Mölder, H., Espak, P., Saumets, A. (eds.). Cultural Crossroads in the Middle East The Historical, Cultural and Political Legacy of Intercultural Dialogue and Conflict from the Ancient Near East to the Present Day. Second revised and expanded edition. Studia Orientalia Tartuensia, Series Nova VIII Tartu: University of Tartu Press.

Mölder, H., Sazonov, V. (2016). Sõjateoloogia ilmingud Lähis-Idas Da'ishi näitel: kas religioosne liikumine või poliitilis-sõjaline organisatsioon? "Sõjateadlane" 2016/3.

Mölder, H., Sazonov, V. (2019). The Development of Intercultural Dialogue in the Middle East: Contemporary Ideological-Religious Conflicts and their Historical Roots [In:] Sazonov, V., Mölder, H., Espak, P. (eds.) Cultural Crossroads in the Middle East: Historical, Cultural and Political Legacy of Intercultural Dialogue and Conflict from Ancient Near East to Present Days. Studia Orientalia Tartuensia, Series Nova VIII, Tartu: University of Tartu Press.

Mölder, H., Sazonov, V. (2021). The Development of Intercultural Dialogue in the Middle East: Contemporary Ideological-Religious Conflicts and their Historical Roots [In:] Sazonov, V., Mölder, H., Espak, P. (eds.) Cultural Crossroads in the Middle East: Historical, Cultural and Political Legacy of Intercultural Dialogue and Conflict from Ancient Near East to Present Days. Second revised and expanded edition. Studia Orientalia Tartuensia, Series Nova VIII, Tartu: University of Tartu Press.

Mushtaq, A. Q., Afzal, M. 2017. Arab Spring: Its Causes and Consequences. "Journal of the Punjab University Historical Society”, Vol. 30(1).

Natali, D. (2015). The Islamic State's Baathist roots. "Al-Monitor”, 24 April 2015 [Access: 21.12.2020]. Access on the internet: https://www.al-monitor.com/pulse/fa/originals/ 2015/04/baathists-behind-the-islamic-state.html

New, D. S. (2002). Holy War. The Rise of Militant Christian, Jewish and Islamic Fundamentalism. Jefferson, North Caroline; London: McFarland \& Company.

Patrikarakos, D. (2016). Apocalypse or Bust: The Battle for Dabiq. "Radio Free Europe”, 9 October 2019 [Access: 21.12.2020]. Access on the internet: https://www.rferl.org/ a/tracking-islamic-state-dabiq-battle-apocalypticism/28040703.html 
Peters, R. (2005). Jihad in classical and modern Islam. A Reader. Updated Edition with a Section on Jihad in 21 st century, Markus Wiener Publishers, Princeton.

Peterson, Ü. (2005). Džihaadi kontseptsiooni kujunemine Koraanis. Master thesis, University of Tartu.

Peterson, Ü. (2016). Sü̈ria kodusõjani viinud sündmustest islami-maailmas ja eriti Sü̈rias. "Akadeemia", 12.

Pink, J. (2010). Tradition and Ideology in Contemporary Sunnite Qur'ānic Exegesis: Qur'ānic Commentaries from the Arab World, Turkey and Indonesia and their Interpretation of Q 5:51. "Die Welt des Islams, Vol 50(1).

Rashid, A. (2002). Jihad. The Rise of Militant Islam in Central Asia. A World Policy Institute Book, Yale University Press, New Haven\&London.

Reuters, Ch. 2015. Secret Files Reveal the Structure of Islamic State. „,Spiegel Online”, April 18 [Access: 2.3.2021]. Access on the internet https://www.spiegel.de/international/ world/islamic-state-files-show-structure-of-islamist-terror-group-a-1029274.html

Roy, O. (2008). The Politics of Chaos in the Middle East. New York: Columbia University Press.

Rózsa, N. et al. (2012). The Arab Spring Its Impact on the Region and on the Middle East Conference. Middle East Conference. "Academic Peace Orchestra Middle East (APOME). Policy Brief for The Middle East Conference on a WMD/DVs Free Zone” No 9/10, August [Access: 2.3.2021]. Access on the internet: http://library.fes.de/pdf-files/iez/09609.pdf

Rubin, B. M. (ed.) (2009). Guide to Islamist Movements. New York, London: M.E. Sharpe, Amonk.

Sazonov, V. (2012). Vanad rivaalid. „Postimees”, 6 February 2012 [Access: 21.12.2020]. Access on the internet: https://arvamus.postimees.ee/729494/vladimir-sazonov-vanadrivaalid

Sazonov, V. (2014a). Nebukadnetsarit järgides: Saddam Hussein ja muistsed Lähis-Ida despoodid. - "Idakiri. Eesti Akadeemilise Orientaalseltsi aastaraamat".

Sazonov, V. (2014b). Outbreaks of Islamism in Iraq - the Rebirth of the Caliphate? "Diplomaatia", 22 September 2014 [Access: 21.11.2019]. Access on the internet: https://icds.ee/outbreaks-of-islamism-in-iraqthe-rebirth-of-the-caliphate.

Sazonov, V., Ploom, I. (2019). Insights Into the Ideological Core and Political Pillars of ISIS. "Sõjateadlane" 13.

Selengut, C. (2003). Sacred Fury: Understanding Religious Violence. Walnut Creek, CA: AltaMira Press.

Sly, L. (2015). How Saddam Hussein's former military officers and spies are controlling Isis. "The Independent", 5 April 2015 [Access: 21.12.2020]. Access on the internet: https://www.independent.co.uk/news/world/middle-east/how-saddam-husseins-formermilitary-officers-and-spies-are-controlling-isis-10156610.html

Spencer, W. J. (2007). The Middle East. Global Studies. Dubuque: A Division of the McGrawHill Companies.

Stern, J., Berger, J. M. (2016). ISIS. Terrori riik. Imeline Ajalugu, Imeline Teadus, AS Äripäev, Tallinn.

The ideology of the Islamic State of Iraq and the Levant.Wikipedia, [Access: 21.12.2020]. Access on the internet: https://en.wikipedia.org/wiki/Ideology_of_the_Islamic_State_ of_Iraq_and_the_Levant\#cite_note-42

Todenhöfer, J. (2016). Ten Days in the Islamic State. My Journey into the Heart of Terror. Vancouver/Berkeley: Greystone Books. 
Trollinger, S. L., Trollinger, W. V. (2017). The Bible and Creationism. "English Faculty Publications" [Access: 21.12.2020]. Access on the internet: http://ecommons.udayton.edu/ eng_fac_pub/105

William, J. (2015). How ISIS uses and abuses Islam. „Vox“, 18.11.2015 [Access: 21.12.2020]. Access on the internet: https://www.vox.com/2015/11/18/9755478/isis-islam

Zgryziewicz, R. (2016). Daesh Strategic Communications [In:] Kudors, A., Pabriks, A. (eds.). The War in Syria: Lessons for the West. The Centre for East European Policy Studies. Rīga: University of Latvia Press.

Zgryziewicz, R., Grzyb, T., Fahmy, Sh., Shaheen J. (2015). Daesh information campaign and its influence, NATO Strategic Communications Centre of Excellence, Riga, 8 January 2016.

DOI: 10.7862/rz.2021.mmr.06

The text was submitted to the editorial office: February 2021.

The text was accepted for publication: March 2021. 